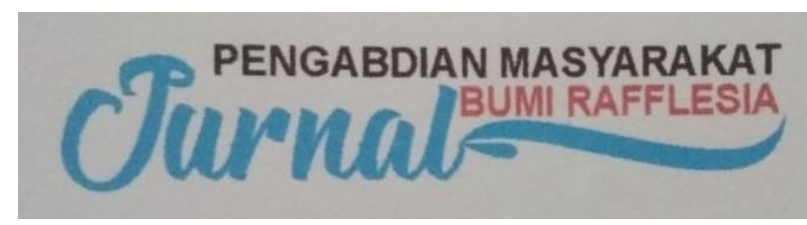

\title{
PENINGKATAN BUDAYA MEMBACA ( LITERASI ) DALAM MASYARAKAT DI KELURAHAN SUMBER JAYA KOTA BENGKULU
}

\author{
Hilyati Milla, Reni Kusmiarti, Helmarini \\ Program Studi Pendidikan Ekonomi, Program Studi Bahasa Indonesia \\ Universitas Muhammadiyah Bengkulu \\ Email : hilyati_milla@yahoo.co.id \& renikusmiarti@umb.ac.id
}

\begin{abstract}
ABSTRAK
Perkembangan tehnologi dan komunikasi mengakibatkan kebiasaan membaca masyarakat terhadap suatu bacaan semakin berkurang Diperlukan sebuah kegiatan yang bertujuan untuk meningkatkan pemahaman masyarakat tentang manfaat kebiasaan membaca dalam keluarga, Program ini dilakukan di desa Sumber Jaya, Kampung Melayu Kota Bengkulu Program kegiaatan ini dilakukan atas beberapa tahapan yaitu (1 ) sosialisasi tentang manfaat membaca dalam keluarga , ( 2 ) Pengadaan bahan bacaan dan membentuk pojok baca di sekolah dan rumah warga. ( 3 ) Mengevaluasi tingkat pemahaman masyarakat dalam membudayakan kebiasaan membaca. Hasil kegiatan ini sangat bervariasi yaitu : (1 ) Adanya kelompok masyarakat yang sudah menyadari tentang pentingnya dan manfaat membaca dan orang tua menyediakan bahan bacaan (2) Kelompok masyarakat yang mampu untuk menyediakan bahan bacaan atau pojok baca dirumah mereka tapi mereka tidak peduli tentang menumbuhkan minat baca pada anggota keluarga mereka (3)Kelompok masyarakat yang menyadari manfaat membaca tapi belum mempunyai kemampuan untuk menyediakan bahan bacaan ( 4 ) Kelompok masyarakat yang belum melaksanakan program kebiasaan membaca karena ketidakmampuan mereka menyediakan bahan bacaan dan juga tidak peduli dalam meningkatkan minat baca pada keluarga mereka
\end{abstract}

Keyword :Budaya Membaca, Literasi, Keluarga . Pemahaman 


\section{PENDAhUluan}

Pengaruh dari perkembangan tehnologi mengakibatkan masyarakat mengalami transisi dalam mengadapi kemajuan dunia digital maupun peralatan canggih yang lain , hal ini menyebabkan adanya kecendrungan masyarakat untuk berkomunikasi tanpa harus melalui bacaan. Seperti yang diketahui bahwa membaca adalah bagian paling sederhana dari makna literasi.Cukup menghadirkan waktu luang dan adanya bahan bacaan. Tetapi bukan perkara mudah untuk masyarakat kita yang terbiasa atau mungkin dimanjakan dengan komunikasi lisan (oral) dibanding tulisan. . Di sini lah perlu adanya perubahan pola pikir, dimana rendahnya minat baca masyarakat adalah sebuah kemunduran yang teramat dahsyat bagi suatu bangsa.Sampai kapan pun, buku tetap menjadi bahan bacaan sekaligus produk intelektual yang tak lekang dimakan zaman.Tapi kini, banyak orang seolah mencukupkan ilmu dengan perangkat elektronik dan jaringan internet.Buku-buku dianggap tidak praktis dan memakan waktu dibanding informasi daring (online) yang kredibilitasnya masih diragukan. Menghidupkan budaya literasi pada masyarakat yang kronis terhadap minat baca membutuhkan kerjasama dan program yang tertata.Membaca bagi sebagian masyarakat (komunitas) memiliki berbagai kendala dan kendalanya ini yang perlu ditangani secara bersama, jika tidak, maka kekuatan pribadi tidak akan mampu menjebol tembok pertahanan arus informasi yang mengglobal. Pemerintah, swasta, masyarakat, sekolah, aparat, dan kelompok jika bersama sama maka akan menjadi kekuatan besar untuk sama sama menyadari pentingnya literasi bagi kemajuan dan kecerdasan masyarakat menuju Indonesia cerdas seutuhnya

Untuk mengantisipasi persoalan diatas, sebagai lembaga yang bergerak dalam bidang pendidikan merasa terpanggil untuk membantu persoalan yang terjadi saat ini, berupaya bagaimana agar masyarkat yang mengenal tehnologi komunikasi juga menyenangi membaca sebagai sarana mencerdaskan bangsa. Untuk membiasakan masyarakar menyenangi membaca perlu dicari pola dengan berbagai strategi, seperti keluarga, sekolah dan lainnya. Keluarga merupakan proses pembelajaran yang pertama dalam mengenalkan kebiasaan membaca seorang anak. Bila orang tua membiasakan anaknya mengenalkan bacaan kepada anak, maka si anak akan merasa terbiasa bahwa membaca tersebut banyak manfaatnya dan menyenangkan . Sekolah merupakan tempat kedua bagi anak dalam menumbuhkembangkan minat baca seorang anak, kegiatan tersebut dapat dalam bentuk penugasan, mengarang, menyalurkan minat anak melalui pengamatan yang harus dituangkan melalui tulisan dan lain sebagainya.

Bentuk kegiatan yang diberikan dalam membiasakan membaca pada masyarakat dan siswa sekolah adalah dengan sosialisasi dan memberikan bahan bacaan yang diperuntukan kepada anak anak usia balita atau masa masa awal sekolah . Sosialisasi ini diberikan kepada orang tua dan masyarakat yang terlibat dalam pengasuhan anak dan sekolah yang berada di lingkungan Kelurahan Sumber Jaya Kampung Melayu Kota Bengkulu merupakan lokasi yang perlu ditingkatkan kebiasaan membaca karena di lokasi ini anak dalam usia pendidikan dasar dan menengah cukup banyak dan dari segi sosio ekonomis perlu perhatian yang lebih .

\section{METODE KEGIATAN}

Metode pelaksanaan kegiatan dalam rangka meningkatkan budaya membaca dalam keluarga dan masyarakat dengan langkah sebagai berikut: 
1. Tahap Persiapan
a. Mengkoordinasikan pelaksanaan program dengan mitra
b. Melakukan persiapan materi sosialisasi
c. Persiapan bahan bacaan penunjang kebiasaan membaca

2. Tahap Pelaksanaan

Melaksanakan sosialisasi tentang hal yang berhubungan dengan menumbuhkan budaya membaca ( literasi) dalam keluarga dan masyarakat, memberikan contoh serta memberikan secara cuma cuma bacaan bagi anak anak sebagai pengenalan terhadap bacaan . Sosialisasi ini dilakukan ditiga lokasi yaitu RT 04 T 22 dan RT 26 Kelurahan Sumber Jaya 'Mengadakan pojok pojok bacaan dalam keluarga dan masyarakat .

3. Tahap Evaluasi

Pada tahap ini akan dilaksanakan evaluasi terhadap pelaksanaan kegiatan PKM pada mitra. Pendampingan dan penilaian atas capaian program yang telah dilaksanakan terhadap mitra dalam hal ini adalah keluarga- yang menerapkan membiasakan membaca bagi keluarga dan masyarakat dengan indicator keberhasilan adalah tersedianya pojok baca dalam rumah tangga di masyarakat Kelurahan Sumber Jaya Kota . Tahab refleksi membahas tentang hasil monitoring dan evaluasi. Diskusi ini untuk mengambil langkah kedepan terhadap persoalan yang terjadi dalam masyarakat berkaitan denga masalah kebiasaan membaca .

\section{HASIL DAN PEMBAHASAN}

Metode pelaksanaan kegiatan dalam rangka meningkatkan budaya membaca dalam keluarga dan masyarakat dilakukan beberapa tahapan kegiatan yang terdiri sebagai berikut:

\section{a. Tahap Persiapan}

Dalam tahap persiapan ini ada beberapa hal yang dilakukan al :

- Observasi kemasyarakat dan sekoah : Observasi kemasyarakat ini dilakukan bersamaan dengan Mahasiswa yang sedang melangsungkan program KKN UMB dengan keikutsertaan mahasiswa, maka kegiatan ini lebih mudah untuk terjun langsung kemasyarakat . Dalam observasi ini di dapat data tentang kondisi masyarakat dimana sebahagian dari masyarakat ini memang kurang mampu untuk mengadakan bahan bacaan dirumah sehingga sangat kecil peluang bagi anaknya untuk membaca bahan bacaan diluar bahan pelajaran mereka. Observasi ke sekolah untuk melihat kondisi sekolah dalam ketersediaan bahan bacaan selain dari bahan pelajaran . Dari pantauan Tim ditemukannya adanya bacaan selain dari bahan mata pelajaran, tapi pemanfaatannya belum maksimal karena belum adanya program Literasi disekolah tersebut.

- Persiapan Materi tentang sosialisasi ke masyarakat dan sekolah,materi sosialisasi ini berkaitan tentang Literasi , meningkatkan minat baca, manfaat membaca

- Persiapan bahan bahan pembuatan Pojok Baca. Pojok baca ini dibuat di sekolah dengan 2 kelas sebagai sampel yaitu kelas 1 dan kelas 4 . Kelas 1 
diambil sebagai pemula dalam mengenalkan baca tulis dan kelas 4 dianggap sebagai kelas lanjut untuk tingkatan sekolah dasar. Pembuatan pojok baca ini di tempatkan di salah satu pojok ruang kelas dengan memberikan hiasan dinding yang menarik perhatian anak untuk tempat membaca . Pojok baca ini juga terdiri atas perlengkapan seperti, karpet, rak buku, daftar piket,

- Penyediaan bahan bacaan yaitu buku yang berkaitan dengan bacaan selain dari bacaan materi pembelajaran . seperti buku komik, buku kisah nabi, buku tentang sejarah pahlawan dan buku lainnya . Buku buku ini di dapat dari sumbangan yang disalurkan , buku koleksi sekolah .

\section{b. Tahap Pelaksanaan}

Tahap sosialisasi ini dilaksanakan di 3 RT dan 1 sekolah madrasah Islamiah yang berada di lingkungan Kelurahan Sumber Jaya ,memberikan contoh serta memberikan secara cuma cuma bacaan bagi anak anak sebagai pengenalan terhadap bacaan . Pelaksanaan sosialisasi ini dilakukan tidak bersamaan di setiap RT dan sekolah karena lokasinya berbeda - Sosialisasi di RT dilakukan di rumah warga dengan mengumpulkan warga melalui bantuan mahasiswa yang sedang melakukan kegiatan KKN , materi sosialisasi diberikan oleh TIM dan mahasiswa materi sosialisasi tentang Menumbuhkan minat baca dan diskusi tentang persoalan yang terdapat dalam keluarga berkaitan dengan pengadaan buku, pengaruh sarana komunikasi Hasil dokumentasi dari pembuatan Pojok Buku yang diadakan di sekolah mitra dapat dilihat pada gambar dibawah ini
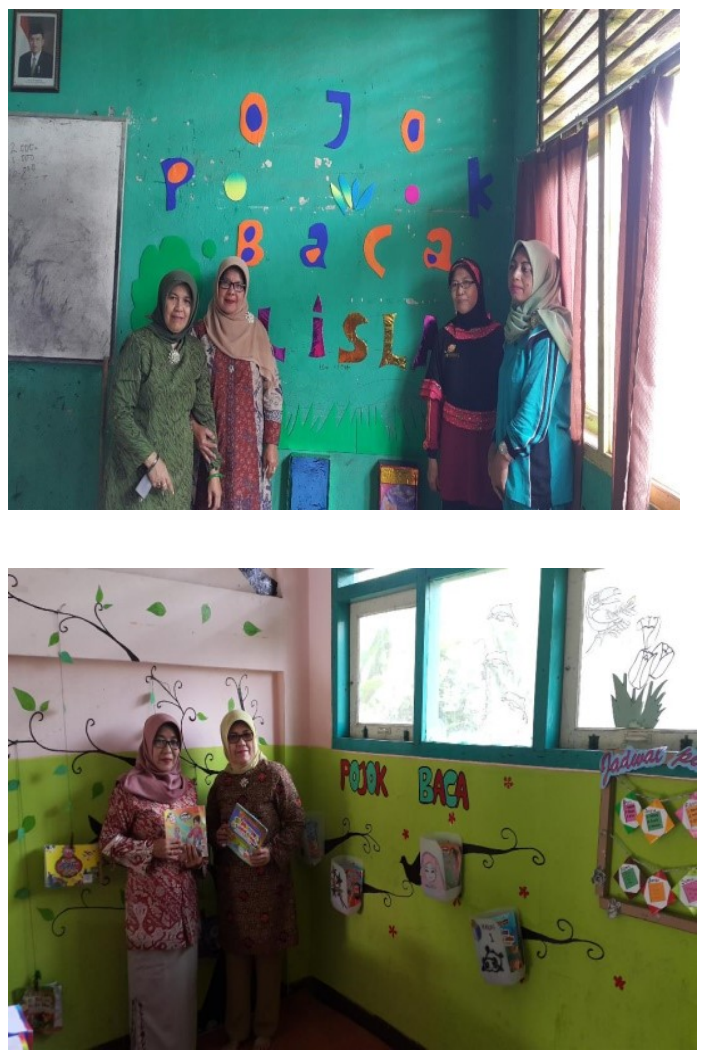

\section{Gambar I : Pojok Baca di Sekolah}

Tahapan pelaksanaan kegiatan yang dilakukan kepada masyarakat dan sekolah yang ada dilokasi seperti terlihat pada tabel 1.di bawah ini ;

\section{Tabel 1:Aktivitas Pelaksanaan Kegiatan Peningkatan Budaya Literasi}

\begin{tabular}{|c|c|c|c|c|}
\hline $\begin{array}{c}\text { RT/ } \\
\text { Sekolah }\end{array}$ & KEGIATAN & $\begin{array}{c}\text { WAK } \\
\text { TU }\end{array}$ & $\begin{array}{c}\text { JUML } \\
\text { AH } \\
\text { PESER } \\
\text { TA } \\
\end{array}$ & KET \\
\hline \multirow[t]{3}{*}{ RT 04} & - Sosialisasi & & $\begin{array}{l}16 \\
\text { warga }\end{array}$ & \multirow{3}{*}{$\begin{array}{l}\text { Tim } \\
\text { dan } \\
\text { Mahasi } \\
\text { swa }\end{array}$} \\
\hline & $\begin{array}{l}\text { - Kunjungan } \\
\text { kerumah } \\
\text { warga } \\
\end{array}$ & & $\begin{array}{l}5 \\
\text { keluarg } \\
\text { a } \\
\end{array}$ & \\
\hline & - Refleksi & & Tim & \\
\hline \multirow[t]{2}{*}{ RT 22} & - Sosialisasi & & $\begin{array}{l}13 \\
\text { warga }\end{array}$ & \multirow{2}{*}{$\begin{array}{l}\text { Tim } \\
\text { dan } \\
\text { Mahas } \\
\text { swa }\end{array}$} \\
\hline & $\begin{array}{l}\text { - Kunjungan } \\
\text { kerumah } \\
\text { warga }\end{array}$ & & $\begin{array}{l}4 \\
\text { keluarg } \\
\text { a }\end{array}$ & \\
\hline
\end{tabular}




\begin{tabular}{|c|c|c|c|}
\hline & - Refleksi & Tim & \\
\hline \multirow[t]{3}{*}{ RT 26} & Sosialisasi & $\begin{array}{l}24 \\
\text { warga }\end{array}$ & \multirow{3}{*}{$\begin{array}{l}\text { Tim } \\
\text { dan } \\
\text { Mahasi } \\
\text { swa }\end{array}$} \\
\hline & $\begin{array}{l}\text { Kunjungan } \\
\text { kerumah } \\
\text { warga }\end{array}$ & $\begin{array}{l}3 \\
\text { keluarg } \\
\text { a }\end{array}$ & \\
\hline & Refleksi & Tim & \\
\hline \multirow[t]{3}{*}{$\begin{array}{l}\text { Madras } \\
\text { ah } \\
\text { Islamia } \\
\mathrm{h}\end{array}$} & Sosialisasi & $\begin{array}{l}30 \\
\text { Guru } \\
\text { TU, } \\
\text { Peg } \\
\text { Pustaka }\end{array}$ & \multirow[t]{3}{*}{$\begin{array}{l}\text { Tim } \\
\text { dan } \\
\text { mahasis } \\
\text { wa }\end{array}$} \\
\hline & $\begin{array}{l}\text { Pembuatan } \\
\text { Pojok Baca }\end{array}$ & 2 kelas & \\
\hline & Refleksi & Tim & \\
\hline
\end{tabular}

\section{c. Tahap Monitoring dan Evaluasi}

Tahap evaluasi ini dilakukan dengan kunjungan kerumah rumah warga melihat apakah ada perobahan masyarakat dan sekoah dalam meningkatkan minat baca . Kegiatan monitoring ini dilakukan dengan mendatangi rumah warga yang pernah ikut program sosialisasi. Pertanyaan yang dilakukan berhubungan dengan apakah ada tindak lanjut dari program sosialisasi yang dilakukan terdahulu . Dari hasil wawancara dan obsevasi dilapangan terdapat beberapa pengelompokan seperti di bawah ini

a. Adanya kelompok masyarakat yang sudah menyadari tentang pentingnya dan manfaat membaca sehingga ada perlakuan orang tua menyediakan bahan bacaan, pengaturan jam bermain atau mengendalikan pemakaian HP bagi anak. Artinya masyarakat sudah mengenalkan budaya literasi pada anggota keluarga

b. Kelompok masyarakat yang mampu untuk menyediakan bahan bacaan atau pojok baca dirumah mereka tapi mereka tidak peduli tentang menumbuhkan minat baca pada anggota keluarga mereka c. Kelompok masyarakat yang menyadari manfaat membaca tapi belum mempunyai kemampuan untuk menyediakan bahan bacaan bagi keluarganya terutama anak anaknya sehingga diperlukan pihak lain yang bersedia turun tangan mengatasi persoalan ini

d. Kelompok masyarakat yang belum melaksanakan program literasi karena ketidakmampuan mereka menyediakan bahan bacaan dan juga tidak peduli dalam meningkatkan minat baca pada keluarga mereka dan juga tidak mempunyai aturan dalam aktivitas sehari hari

e. Untuk sekolah : Pojok baca yang sudah di adakan belum dimanfaatkan secara maksimal karena sekolah tersebut belum menyusun jadwal literasi yang dilakuakan diawal pelajaran . Sehingga program literasi ini akan diberlakukan saat penyusunan jadwal semester yang akan datang, namun memanfaatkan pojok baca dilakukan tidak terjadwal artinya kapan ada waktu luang .

\section{d. Tahap Refleksi}

Reflesi yang dilakukan terhadap kegiatan berupa respon masyarakat terhadap program kegiatan, memunculkan sebuah pemikiran bahwa kebiasaan membaca atau budaya membaca dalam masyarkat terutama dalam lingkungan keluarga dan disekkepada masyarakat. olah me. Program tersebut bisa terkait dengan program pembelajaran, maupun aktifitas langsung merlukan dukungan pemerintah refleksi ini dilakukan pengkajian tentang respon masyarakat terhada pprgram kegiatan yang dilakukan - Perlu adanya uluran tangan dari pemerintah atau pihak lain yang 
mensuport bahan bacaan, atau pustaka keliling mengunjungi daerah tersebut

a. Kembali mensuport warga secara berkesinambungan tentang budaya literasi dan manfaatnya dalam mencerdaskan warga/ bangsa.

b. Bagi sekolah, menjalankan program literasi dengan efektif, terprogram

Berdasarkan tahapan tahapan di atas maka pelaksanaan program literasi bagi masyarakat

\section{PENUTUP}

\section{A. KESIMPULAN}

a. Kelompok masyarakat yang sudah menyadari manfaat membaca dan menyediakan bahan bacaan bagi anggota keluarganya

b. Kelompok masyarakat yang menyadari manfaat membaca namun tidak punya kemampuan untuk menyediakan bahan bacaan

c. Kelompok masyarkat yang tidak menyadari manfaat membadan tidak membiasakan budaya membaca namun mereka mampu untuk mengadaan bahan bacaan

d. Kelompok masyarakat ting tidak menyadari manfaan membaca serta tidak membudayakan kebiasaan membaca dalam keluarga karena mereka tidak mampu untuk mengadakan bahan bacaan

e. Bagi sekolah, sudah tersedianya pojok baca, namun belum semua kelas

\section{B. SARAN}

a. Perlu adanya uluran tangan dari pemerintah atau pihak lain yang mensuport bahan bacaan, atau pustaka keliling mengunjungi daerah tersebut

b. Kembali mensuport warga secara berkesinambungan tentang budaya literasi dan manfaatnya dalam mencerdaskan warga/ bangsa

c. Bagi sekolah, menjalankan program literasi harus efektif, terprogram

\section{DAFTAR PUSTAKA .}

Koswara Engkos, ( editor ) 2005, Dinamika Informasi dalam Era Globalisasi. Bandung : IPI dan Remaja Rosdakarya

Bobbi De Porter\& Mike hernaci ( 2003 ) Quantum learning: Membiasakan membaca nyaman dan Menyenangkan . Kaifa bandung

Tim Penulis MPK. Bahasa

Indonesia.2011:Menulis Ilmiah: Buku Ajar MPK Bahasa Indonesia

Surabaya. Unesa University Press

Kemendikbud ( 2016 ) Panduan Gerakan Literasi di SMA , Dirjen Dikdasmen, Jakarta

Kemendikbud ( 2016 ) Panduan Gerakan Literasi di SMP , Dirjen Dikdasmen, Jakarta

Kemendikbud ( 2016 ) Panduan Gerakan Literasi di SD, Dirjen Dikdasmen, Jakarta

Kemendikbud ( 2016 ) Panduan Gerakan Literasi di SMK , Dirjen Dikdasmen, Jakarta 